\title{
PERENCANAAN GURU MADRASAH ALIYAH JAMBI DALAM PEMBELAJARAN MATEMATIKA PADA KURIKULUM TINGKAT SATUAN PENDIDIKAN
}

\author{
Dian Nisa Istofa ${ }^{1}$ dan Marni Zulyanty ${ }^{2}$ \\ ${ }^{1,2}$ Universitas Islam Negeri Sulthan Thaha Saifuddin Jambi
}

Info Artikel

Sejarah Artikel:

Diterima 9 Agt 2018

Direvisi 5 Sept 2018

Disetujui 29 Okt 2018

Keywords: Perencanaan Guru, Pembelajaran Matematika.KTSP

Paper type:

Research paper

\begin{abstract}
School readiness in implemention of mathematics learning based on the education unit level curriculum is an important factor to see the effectiveness is using of the education unit level curriculum. One aspect to know the effectiveness of curriculum use is to look at learning planning activities. So that this research was conducted with the aim of looking at the readiness of madrasah aliyah's teacher in learning mathematics in planning the education unit level curriculum. This research is a study of the implementation of the education unit level curriculum on learning mathematics, especially in the planning areas. This research was conducted at Muaro Jambi Madrasah Aliyah Negeri 4 school. This study uses descriptive qualitative approach. This research emphasizes more on the Madrasah Aliyah plan on mathematics learning by using the education unit level curriculum in mathematics learning. The subject of this study was the mathematics teacher at Madrasah Aliyah Negeri 4 Muaro Jambi. Data collection techniques in this collection are carried out through observations of the situation of mathematics learning by using KTSP, interviews about teacher planning in preparing mathematics learning in the education unit level curriculum in madrasah aliyah. Based on the results of this research, the readiness of the teacher in developing the syllabus and RPP is in accordance with the provisions that must be in the reference of the education unit level curriculum. Where the components contained in the syllabus and RPP made by the teacher have included these components. In addition, the teacher has also analyzed the purpose of mathematics learning, namely the conformity of the competency standard with the learning material that will be delivered. Mathematics teacher readiness is also shown by understanding the different characters of students in each class
\end{abstract}

\begin{abstract}
Abstrak
Kesiapan sekolah dalam melaksanakan pembelajaran matematika berdasarkan kurikulum tingkat satuan pendidikan menjadi faktor penting untuk melihat keefektifan pengunaan kurikulum tingkat satuan pendidikan. Salah satu aspek untuk melihat keefektifan penggunaan kurikulum adalah dengan melihat kegiatan perencanaan pembelajaran. Sehingga penelitian ini dilakukan dengan tujuan melihat kesiapan guru madrasah aliyah pada pembelajaran matematika dalam perencanaan kurikulum tingkat satuan pendidikan. Penelitian ini merupakan sebuah studi tentang implementasi kurikulum tingkat satuan pendidikan pada pembelajaran matematika khususnya dalam ranah perencanaan. Penelitian ini dilakukan di sekolah Madrasah Aliyah Negeri 4 Muaro Jambi. Penelitian ini menggunakan pendekatan kualitatif deskripitif. Penelitian ini lebih menekankan pada perencanaan guru MA pada pembelajaran matematika dengan menggunakan kurikulum tingkat satuan pendidikan pada pembelajaran matematika. Adapun subjek dalam penelitian ini adalah guru matematika Madrasah Aliyah Negeri 4 Muaro Jambi. Teknik pengumpulan data dalam pengumpulan ini dilakukan melalui observasi tentang situasi pembelajaran matematika dengan menggunakan KTSP, wawancara tentang perencanaan guru dalam mempersiapkan pembelajaran matematika pada kurikulum tingkat satuan pendidikan di madrasah aliyah. Berdasarkan hasil penelitian, kesiapan guru dalam mengembangkan silabus dan RPP sudah sesuai dengan ketetapan yang harus ada dalam acuan kurikulum tingkat satuan pendidikan. Dimana komponen-komponen yang ada dalam silabus dan RPP yang dibuat guru telah memuat komponen tersebut. Selain itu guru juga telah menganalisis tujuan pembelajaran matematika yaitu kesesuaian standar kompetensi dengan materi pembelajaran yang akan disampaikannya. Kesiapan guru matematika juga ditunjukkan dengan memahami karakter siswa yang berbeda dalam setiap kelas.
\end{abstract}

(C) 2018 Universitas Muria Kudus 


\section{PENDAHULUAN}

Menurut Undang-Undang Nomor 20 Tahun 2003 tentang Sistem Pendidikan Nasional, pembelajaran merupakan proses interaksi peserta didik dengan pendidik dan sumber belajar pada suatu lingkungan belajar. Oleh karenanya dalam pembelajaran terjadi hubungan timbal balik diantara semua komponen yang terlibat dalam pembelajaran.

Pembelajaran secara formal dilakukan di sekolah. Sekolah merupakan suatu lembaga di mana seorang peserta didik menuntut ilmu dan merupakan wadah bagi para peserta didik dalam menentukan arah yang ingin ditempuh serta untuk menentukan cita-cita yang ingin mereka capai untuk masa depannya (Yeni, et al, 2017). Selain itu, sekolah merupakan tempat anak didik menukar pikiran dengan rekan-rekan dan mendapat suatu perhatian yang baik dari para pendidik (guru).

Pendidikan sekolah merupakan kesinambungan dari pendidikan dalam keluarga, yang mana pendidikan sekolah bersifat formal dan dijalankan sesuai dengan ketentuanketentuan yang berlaku. Idealnya menurut Kompri (2014) pendidikan sekolah biasanya dilakukan pada sebuah lembaga yang terdiri dari kelas-kelas, memiliki jenjang, adanya kurikulum pembelajaran, ada tujuan, perencanaan dan lainlain.

Pendidikan formal menggunakan kurikulum yang digunakan sebagai pedoman pelaksanaan pembelajaran. Kurikulum yang masih digunakan dalam pembelajaran sekolah madrasah aliyah adalah kurikulum tingkat satuan pendidikan (KTSP). Di jambi masih 30\% sekolah MA yang menggunakan kurikulum KTSP tersebut. Evaluasi pembelajaran dalam Kurikulum Tingkat Satuan Pendidikan menerapkan sistem penilaian berkelanjutan untuk mengungkap keberhasilan belajar siswa dari aspek kognitif, afektif, dan psikomotorik.

Kurikulum merupakan komponen terpenting dalam pendidikan untuk dijadikan acuan oleh satuan pendidkan (Mattarima, et al, 2011), baik oleh pengelola maupun penyelengara khususnya oleh guru dan kepala dalam pembelajaran. Dimana kurikulum disusun dan dikembangkan oleh guru dalam implementasinya. Disinilah peran penting guru dalam kurikulum tingkat satuan pendidikan. kurikulum tingkat satuan pendidikan merupakan upaya untuk menyempurnakan kurikulum agar lebih familiar dengan guru, karena mereka banyak dilibatkan dalam pembelajaran dan diharapkan memiliki tanggungjawab yang memadai. Selain itu menurut Mulyasa (2008) penyempurnaan kurikulum yang berkelanjutan merupakan keharusan agar sistem pendidikan nasional selalu relevan dan kompetitif.

Implementasi Kurikulum Tingkat Satuan Pendidikan adalah bagaimana menyampaikan pesan-pesan kepada peserta didik untuk membentuk kompetensi mereka sesuai dengan karakteristik dan kemampuan masing-masing. tugas guru dalam implementasi Kurikulum Tingkat Satuan Pendidikan adalah bagaimana memberikan kemudahan belajar (facilitate of learning) kepada peserta didik, agar mereka mampu berinteraksi dengan lingkungan eksternal sehingga terjadi perubahan perilaku sesuai dengan yang dikemukakan dalam Standar Isi (SI) dan Standar Kompetensi Lulusan (SKL).Selain itu tentang bagaimana meningkatkan kualitas guru sebagai tenaga pengajar bagi peserta didik terutama dalam mengorganisasikan materi pembelajaran, guru diharapkan secara professional mampu menyampaikan materi dengan baik, karena itu merupakan tugas utama seorang guru. Disamping itu, guru diharapkan mampu berperan sebagai perencana, pelaksana, dan pengevaluasi terhadap materi pembelajaran yang disampaikan pada peserta didik.

Komponen-komponen dalam kurikulum antara lain komponen tujuan, isi, metode, serta komponen evaluasi. Dalam Permendiknas Nomor 41 tahun 2007 menyatakan bahwa selain buku teks pelajaran, guru menggunakan buku panduan guru, buku pengayaan, buku referensi dan sumber belajar lainnya. Oleh karena itu, guru harus dapat secara mandiri mengembangkan bahan ajar sesuai karakteristik sekolah masingmasing.

Banyak kasus yang terjadi di sekolah terkait penerapan kurikulum. Salah satunya adalah sekolah dan guru tidak memiliki pertimbangan dalam memilih bahan ajar yang disiapkan untuk peserta didiknya. Alhasil buku yang dipilih sekolah ternyata menggunakan bahasa dengan tingkat pemahaman yang sulit untuk diterima.

Pelajaran matematika merupakan salah satu pelajaran yang terdapat pada pendidikan formal. Pelajaran matematika merupakan dasar dari pelajaran-pelajaran yang lain, seperti ekonomi, sejarah, olahraga dan lain-lain. Penggunaan matematika dalam pelajaran tersebut dikarenakan dalam penerapannya pelajaranpelajaran tersebut sering menggunakan unsur matematika (Swan, et al, 2010) seperti bilangan, nilai hitung dan sebagainya. Matematika merupakan mata pelajaran yang menyenangkan 
dan tidak membosankan, karena dalam kehidupan sehari-hari kita sudah melibatkan logika dan perhitungan, dimana logika dan ilmu hitung adalah bagian dari matematika.

Salah satu karakteristik matematika adalah mempunyai objek yang bersifat abstrak. Sifat abstrak ini menyebabkan banyak siswa mengalami kesulitan dalam belajar matematika. Abdurrahman (2012) mengungkapkan pembelajaran matematika merupakan pembelajaran yang mampu mengembangkan potensi siswa sebab matematika adalah bahasa simbolik yang fungsinya untuk mengekspresikan hubungan kuantitatif dan keruangan sedangkan fungsi teoritisnya adalah untuk memudahkan berfikir.

Kesiapan sekolah dalam melaksanakan pembelajaran Matematika berdasarkan Kurikulum Tingkat Satuan Pendidikan menjadi faktor penting untuk melihat keefektifan pengunaan kurikulum tingkat satuan pendidikan. Salah satu aspek untuk melihat keefektifan penggunaan kurikulum adalah dengan melihat kegiatan perencanaan pembelajaran. Hal ini berarti melihat kesiapan dalam merencanakan semua hal demi terlaksananya proses pembelajaran yang sesuai dengan tujuan pembelajaran. Kegiatan perencanaan menjadi penting, hal ini sesuai dengan pendapat Santrock (2011) bahwa perencanaan berbasis sekolah yang terkoordinasi, pembelajaran dan kurikulum yang berkualitas tinggi, serta lingkungan sekolah yang mendukung dibutuhkan untuk menangani perilaku bermasalah para siswa.

Berdasarkan grand tour dan grand teori diatas peneliti mengadakan penelitian yang bersifat analisis kesiapan guru dalam perencanaan penggunaan Kurikulum Tingkat Satuan Pendidikan. Dimana tujuan penelitian adalah melihat kesiapan guru madrasah aliyah pada pembelajaran matematika dalam perencanaan kurikulum Tingkat Satuan Pendidikan.

\section{METODE PENELITIAN}

Penelitian ini merupakan sebuah studi tentang implementasi Kurikulum Tingkat Satuan Pendidikan pada pembelajaran matematika khususnya dalam ranah perencanaan. Penelitian ini dilakukan di sekolah Madrasah Aliyah Negeri 4 Muaro Jambi. Penelitian ini menggunakan pendekatan kualitatif deskripitif. Penelitian deskriptif merupakan penelitian yang memberi uraian mengenai fenomena atau gejala sosial yang diteliti dengan mendeskripsikan tentang nilai variabel mandiri, baik satu variabel atau lebih (Iskandar, 2008). Selain itu tujuan penelitian deskriptif adalah untuk menjelaskan suatu keadaan, peristiwa, objek dan segala sesuatu yang bisa di jelaskan baik dengan angkaangka maupun kata-kata. Penelitian ini lebih menekankan pada perencanaan guru MA pada pembelajaran matematika dengan menggunakan Kurikulum Tingkat Satuan Pendidikan pada pembelajaran matematika.

Adapun subjek dalam penelitian ini adalah guru matematika madrasah aliyah Negeri 4 Muaro Jambi. Subjek penelitian diambil dengan pendekatan purposive sampling yang dalam penetapannya sesuai dengan tujuan penelitian (Arikunto, 2006)

Hal yang berkaitan dengan metodologi penelitian adalah data penelitian. Data penelitian adalah thing know or as sumed, yang berarti data itu sesuatu yang diketahui atau dianggap. Diketahui, artinya sesuatu yang sudah terjadi sebagi fakta empirik (bukti yang ditemukan secara empiris melalui penelitian). Adapun manfaat data adalah, pertama untuk mengetahui atau memperoleh gambaran tentang sesuatu keadaan atau persoalan. Kedua, untuk membuat keputusan atau memecahkan persoalan. Karena persoalan yang timbul itu ada penyebabnya, maka memecahkan persoalan maksudnya menghilangkan faktor-faktor yang menyebabkan timbulnya persoalan tersebut. Data penelitian diambil dari sumber data penelitian.

Sumber data terdiri atas jenis-jenis informasi yang diperoleh peneliti dari subjek penelitiannya dan dijadikan sebagai responden atau informan. Sumber data yang dipergunakan dalam penelitian ini, terdiri dari: a) manusia; yaitu guru matematika di Madrasah Aliyah, b) kondisi dan aktivitas pembelajaran, c) dokumen, yaitu berupa arsip, dokumen resmi, brosur, profil, jurnal, buku panduan, struktur organisasi dan lain-lain

Teknik pengumpulan data dalam pengumpulan ini dilakukan melalui observasi tentang situasi pembelajaran matematika dengan menggunakan KTSP, wawancara tentang perencanaan guru dalam mempersiapkan pembelajaran matematika pada Kurikulum Tingkat Satuan Pendidikan di Madrasah Aliyah. Terdapat enam tahap dalam proses menganalisis dan menginterpretasikan data kualitatif yaitu (1) menyiapkan dan mengumpulkan data untuk dianalisis, (2) mengembangkan dan mengkode data, (3) membuat kode berdasarkan deskripsideskripsi, (4) menyajikan dan melaporkan hasil yang ditemukan, (5) menginterpretasikan hasil 
yang ditemukan, (6) memvalidasi keakuratan dari hasil yang ditemukan (Creswell, 2012).

\section{HASIL DAN PEMBAHASAN}

Kegiatan perencanaan berisikan kegiatan untuk menentukan apa yang akan dilakukan. Perencanaan berisi rangkaian putusan yang luas dan penjelasan-penjelasan tentang tujuan, penentuan kebijakan, penentuan program, penentuan metode-metode dan prosedur tertentu dan penentuan kegiatan berdasarkan jadwal sehari-hari.

Dalam sebuah proses belajar mengajar seorang guru dituntut untuk dapat mempersiapkan bahan-bahan yang akan digunakan untuk mengajar. Persiapan ini dimaksudkan agar proses yang akan dilaksanakan menjadi teratur, rapi, dan terencana sehingga memudahkan pelaksanaan proses belajar tersebut. Selain hal ini persiapan yang dilakukan juga dapat mendukung agar tujuan pembelajaran yang dilakukan tercapai dengan baik, efektif dan efisien. Selain itu persiapan mengajar akan membantu guru dalam mengorganisasikan materi standar, serta mengantisipasi peserta didik dan masalahmasalah yang mungkin timbul dalam pembelajaran.

Perencanan pembelajaran terdiri dari seperangkat sarana atau alat pembelajaran yang berisikan materi pembelajaran, metode, batasanbatasan, dan cara mengevaluasi yang didesain secara sistematis dan menarik dalam rangka mencapai tujuan yang diharapkan, yaitu mencapai kompetensi atau sub kompetensi dengan segala kompleksitasnya (Chosim et al, 2008). Dari pengertian ini bahan ajar bisa juga disamakan dengan perangkat pembelajaran berupa silabus atau Rencana Pelaksanaan Pembelajaran (RPP).

Kegiatan perencanan pembelajaran matematika dimulai dengan memilih dan menetapkan materi yang akan di sampaikan dan menetapkan metode dan strategi yang sesuai dan mampu untuk mencapai tujuan instruksional pembelajaran. Materi tersebut tentunya terdiri dari serangkaian pokok-pokok bahasan yang harus ditata urutannya dan saling berkaitan satu sama lain. Di dalam memilih pokok-pokok bahasan tersebut, tentunya telah diketahui dan ditetapkan kegunaan dan tujuan dari setiap pokok bahasan, yang pada dasarnya setiap tujuan instruksional pokok bahasan ditujukan untuk menunjang tercapainya tujuan mata pelajaran. Selanjutnya, dari setiap pokok bahasan yang telah ditetapkan tujuannya itu, dijabarkan lebih rinci menjadi beberapa sub pokok bahasan sehingga mampu untuk menetapkan sasaransasaran belajar. Sasaran belajar merupakan gambaran kemampuan siswa (learning outcomes) yang bisa diamati dan diukur.

Kegiatan belajar mengajar harus tetap berpedoman pada rencana pelaksanaan pembelajaran yang telah dibuat oleh guru, Seorang guru dituntut untuk menyiapkan dan merencanakan kegiatan pembelajaran dengan sebaikbaiknya dalam rangka mencapai keberhasilan kegiatan pembelajaran secara optimal. Ketidaksiapan guru dalam menyusun perangkat pembelajaran dipengaruhi oleh sikap guru yang kurang tanggap dalam merespon perubahan kurikulum secara menyeluruh.

Materi pembelajaran matematika menempati posisi yang penting dari keseluruhan kurikulum, yang harus dipersiapkan agar pelaksanaan pembelajaran dapat mencapai sasaran. Sasaran tersebut harus sesuai dengan Standar Kompetensi dan Kompetensi Dasar yang harus dicapai oleh peserta didik. Artinya, materi yang ditentukan untuk kegiatan pembelajaran matematika hendaknya materi yang benar-benar menunjang tercapainya standar kompetensi dan kompetensi dasar, serta tercapainya indikator.

Setiap guru yang mengajar mata pelajaran di tingkat satuan pendidikan, wajib memiliki kompetensi pengembangan silabus dan Rencana Pelaksanaan Pembelajaran (RPP). Sebab kompetensi inilah sebagai bekal seorang guru dalam membuat perencanaan proses kegiatan pembelajaran. Seorang guru yang belum memiliki kompetensi ini, tentunya mengajar tanpa perencanaan yang mempunyai haluan yang jelas, sehingga melahirkan hasil belajar yang tidak memenuhi standar. Dengan demikian bahwa satuan pendidikan sangat membutuhkan tenaga pendidik yang mampu mengembangan silabus dan Rencana Pelaksanaan Belajar (RPP) secara benar. Sementara dewasa ini banyak para tenaga pendidik, baik pada tingkat dasar maupun tingkat menengah belum memahami secara benar tentang pengembangan silabus dan Rencana Pelaksanaan Belajar (RPP).

Peraturan Pemerintah (PP) Nomor 19 tahun 2005 Pasal 20 juga mengsyaratkan bahwa guru diharapkan mengembangkan materi pembelajaran. Berkenaan dengan pemilihan materi pembelajaran ini, secara umum masalah dimaksud meliputi cara penentuan jenis materi, kedalaman, ruang lingkup, urutan penyajian, perlakuan (treatment) terhadap materi pembelajaran. Berdasarkan data observasi, 
dokumentasi dan wawancara pada kelas $\mathrm{X}$ Madrasah Aliyah Negeri 4 Muaro Jambi.

Tabel 1. Kegiatan Perencanaan Guru

Matematika Kelas

\begin{tabular}{lll}
\hline No & Sumber & Kegiatan Perencanaan \\
\hline 1 & Wawancara & $\begin{array}{l}\text { Membuat RPP, kalender } \\
\text { pembelajaran, program tahunan, } \\
\text { program semester, Silabus }\end{array}$ \\
2 & Observasi & $\begin{array}{l}\text { Membuat RPP dan silabus } \\
3\end{array}$ \\
Dokumentasi & Membuat RPP \\
\hline
\end{tabular}

Hasil wawancara dan pemahaman peneliti tentang dokumen dan pengamatan yang didapat peneliti dari guru kelas $\mathrm{X}$ tahun pelajaran 2016/2017 yaitu tentang perencanaan pembelajaran di Madrasah Aliyah Negeri 4 Muaro Jambi yang dilaksanakan oleh guru matematika yaitu para guru bahwa para guru sudah membuat perencanaan pembelajaran yaitu rencana pelaksanaan pembelajaran (RPP), dan membuat kalender pendidikan, menghitung minggu efektif, membuat program tahunan, program semester,dan silabus.

Perencanaan pembelajaran berupa Rencana pelaksanaan pembelajaran (RPP) berfungsi sebagai pedoman bagi guru dalam melaksanakan pembelajaran di kelas, karena didalamnya mengandung kegiatan belajar mengajar yang terdiri dari tujuan, metode, media, kegiatan mengajar, materi, dan evaluasi. Sehingga dapat terlaksana secara maksimal dalam pembelajaran. Rencana Pelaksanaan Pembelajaran disusun oleh masing-masing guru. Secara umum, Rencana Pelaksanaan Pembelajaran yang disusun oleh guru matematika Madrasah Aliyah Negeri 4 Muaro Jambi sudah sesuai dengan konsep Kurikulum Tingkat Satuan Pendidikan. Rencana Pelaksanaan Pembelajaran yang disusun guru meliputi: standar kompetensi, kompetensi dasar, indikator, alokasi waktu, tujuan pembelajaran, materi pembelajaran, media pembelajaran, metode pembelajaran,referensi buku, kegiatan pembelajaran seperti eksplorasi, eloborasi dan konfirmasi, dan diakhiri dengan penilaian hasil belajar siswa. Karena Rencana Pelaksanaan Pembelajaran (RPP) merupakan penjabaran lanjutan dari silabus dan juga merupakan komponen terpenting dari Kurikulum Tingkat Satuan Pendidikan.
Tabel 2. Tujuan Perencanaan Guru Matematika Kelas X MAN 4 Muaro Jambi

\begin{tabular}{|c|c|c|c|}
\hline No & $\begin{array}{l}\text { Kegiatan } \\
\text { Perencanaan }\end{array}$ & Tujuan & $\begin{array}{l}\text { Pedoman } \\
\text { Perencanaan }\end{array}$ \\
\hline 1. & Membuat RPP & $\begin{array}{l}\text { Menjadi pedoman } \\
\text { guru dalam } \\
\text { melaksanakan } \\
\text { pembelajaran }\end{array}$ & $\begin{array}{l}\text { Kurikulum } \\
\text { Tingkat } \\
\text { Satuan } \\
\text { Pendidikan }\end{array}$ \\
\hline 2. & $\begin{array}{l}\text { Membuat } \\
\text { Silabus }\end{array}$ & $\begin{array}{l}\text { Mempermudah } \\
\text { guru dalam } \\
\text { merancang materi } \\
\text { pembelajaran } \\
\text { untuk mencapai } \\
\text { tujuan }\end{array}$ & $\begin{array}{l}\text { Silabus dari } \\
\text { sekolah yang } \\
\text { di } \\
\text { kembangkan } \\
\text { dan di } \\
\text { sesuaikan } \\
\text { dengan mata } \\
\text { pelajaran }\end{array}$ \\
\hline
\end{tabular}

Perencanaan lain seperti silabus di Madrasah Aliyah Negeri Muaro Jambi sudah ada, mereka hanya mengembangkan dari sekolah sesuai dengan mata pelajaran masing-masing. Silabus berfungsi untuk mempermudah guruguru dalam merancang materi-materi pembelajaran dalam mencapai tujuan pembelajaran. Silabus yang disusun guru-guru matematika sudah sesuai dengan pedoman pengembangan silabus berbasis Kurikulum Tingkat Satuan Pendidikan yaitu mencakup standar kompetensi, kompetensi dasar, materi pembelajaran, kegiatan pembelajaran, indikator, penilaian, alokasi waktu, dan sumber belajar.

Berdasarkan analisis dokumen, ada dua guru yang tidak membawa Rencana Pelaksanaan Belajar (RPP). Guru mengaku bahwa untuk merencanakan kegiatan pembelajaran, tidak setiap kali harus dituangkan secara tertulis, tetapi cukup dalam pikiran saja. Hal tersebut dipengaruhi oleh masa tugas yang rata-rata telah berlangsung lama sehingga untuk melaksanakan kegiatan pembelajaran, kadang guru merasa tidak perlu membawa Rencana Pelaksanaan Belajar (RPP) dan silabus.

Selain itu, guru mengaku rutinitas dan adanya tugas selain guru, kadang tidak memungkinkan bagi guru untuk membawa perangkat mengajar setiap hari. Hal ini menunjukkan ketidaksiapan guru dalam merencanakan pembelajaran.

Salah satu strategi penting dalam pembelajaran di sekolah adalah penguasaan terhadap karakter siswa. Guru perlu mengetahui seluk beluk dan karakter siswa yang beragam dalam satu kelas, bahkan dalam satu sekolah. Sebenarnya hal ini bukanlah hal baru dalam dunia pendidikan. Kurikulum kurikulum tingkat satuan pendidikan, telah mengisyaratkan akan pentingnya mempertimbangkan karakter siswa dalam pendidikan di lembaga sekolah. Penting bagi para guru mengenali karakter anak sebelum mengajar. 
Setiap anak memiliki karakter yang berbeda-beda. Hal itu perlu dipahami para guru. Seorang guru bukan hanya sebagai pengajar, tetapi juga sebagai psikolog. Minimal, seorang guru dapat mengenali karakter anak dari kebiasaan sehari-hari di sekolah. Hal tersebut akan sangat membantu guru dalam melakukan menentukkan strategi dalam menyampaikan bahan ajar agar dapat dipahami oleh siswanya.

Perbedaan karakter akan berlaku pula pada perbedaan gaya belajar siswa. Anak dengan gaya belajar tersebut akan cenderung memahami sesuatu lewat hal yang didengar, sedangkan anak dengan gaya belajar visual akan memahami sesuatu lewat hal yang dilihat. Berbeda dengan itu, anak dengan gaya belajar read/write akan memahami sesuatu lewat proses membaca dan menulis, sedangkan anak dengan gaya belajar kinestetik akan memahami sesuatu setelah mencoba melakukannya sendiri.

Satu langkah penting yang perlu dilakukan seorang guru adalah menciptakan suasana belajar yang aman, nyaman, dan menarik bagi anak didiknya. Hal tersebut dapat diwujudkan dengan memberlakukan semacam kesepatan yang nantinya menjadi aturan yang harus dipahami dan dilakukan anak. Aturan ini dibarengi dengan pemberian reward sebagai bentuk apresiasi dan sebagai konsekuensi logis atas pelanggaran yang dilakukan anak. Selain itu, melibatkan siswa dalam aktivitas belajar secara aktif dan intens terkhusus dalam pelajaran matematika merupakan langkah tepat.

Berdasarkan hasil data wawancara, observasi dan dokumentasi dapat disimpulkan bahwa guru dalam mengorganisasikan bahan ajar matematika sebelum menyampaikan bahan ajar tersebut dinilai sudah cukup matang. Hal ini dapat dilihat dari, pertama, persiapan guru dalam merancang silabus dan Rencana Pelaksanaan Belajar (RPP), kedua, menganalis tujuan pembelajaran dengan bahan ajar dan menentukan materi ajar, ketiga, memahami karakteristik siswa.

\section{SIMPULAN}

Kesimpulan yang diperoleh dari penelitian ini adalah beberapa kesiapan guru madrasah aliyah dalam merencanakan pembelajaran matematika pada Kurikulum Tingkat Satuan Pendidikan di Negeri 4 Muaro Jambi yaitu: Pertama, Kesiapan guru dalam mengembangkan silabus dan RPP sudah sesuai dengan ketetapan yang harus ada dalam acuan Kurikulum Tingkat Satuan Pendidikan. Dimana komponen-komponen yang ada dalam silabus dan RPP yang dibuat guru telah memuat komponen standar kompetensi, kompetensi dasar, indikator, materi pembelajaran, kegiatan pembelajaran, penilaian, waktu dan sumber belajar.

Kedua, kegiatan menganalisis tujuan pembelajaran matematika juga dilakukan oleh guru. Hal ini dilakukannya untuk menentukan kesesuaian standar kompetensi dengan materi pembelajaran yang akan disampaikannya, selain itu dengan menganalisis tujuan pembelajaran dapat mengetahui aspek materi kognitif, afektif dan psikomotorik yang sesuai dengan materi pembelajaran yang akan disampaikan. Walaupun pada akhirnya ada guru yang merasa kebingungan untuk menentukan aspek materi afektif dan psikomotorik. Menurutnya muatan pelajaran matematika di madrasah aliyah penuh dengan materi konsep dan materi prosedur yang harus dikuasai siswa. Ketiga, Kesiapan guru matematika juga ditunjukkan dengan memahami karakter siswa yang berbeda dalam setiap kelas.

\section{UCAPAN TERIMAKASIH}

Penulis ucapkan terimakasih kepada segenap Tim Pengelola Jurnal Anargya yang telah memberi kesempatan untuk mempublikasikan karya ilmiah.

\section{DAFTAR PUSTAKA}

Abdurahman, M. 1999. Pendidikan Bagi Anak Berkesulitan Belajar. Jakarta : PT. Rineka Cipta

Abdurahman, M. 2012. Anak Berkesulitan Belajar. Jakarta: PT. Rineka Cipta.

Arikunto, S. 2006. Prosedur Penelitian. Jakarta: PT. Rineka Cipta

Chomsin, S et, al. 2008. Panduan Menyusun Bahan Ajar Berbasis Kompetensi. Jakarta: PT. Elek Media Komputindo

Creswell, Jhon W. 2012. Educational Research "Planning, Conducting, and Evaluating Quantitative and Qualitative Research". Amerika : Pearson

Iskandar. 2008. Metodologi Penelitian Pendidikan dan Sosial. Jakarta: GP Press

Kompri. 2014. Manajemen Sekolah: Teori dan Praktek. Bandung: Alfabeta

Mattarima, et, al. 2011. The Teaching Constraints of English as a Foreign Language in Indonesia: The Context of School Based Curriculum. Sosiohumanika, 4 (2): 287-300

Mulyasa, E. 2008. Implementasi Kurikulum Tingkat Satuan Pendidikan: 
Kemandirian guru dan Kepala Sekolah. Jakarta: Bumi Aksara

Santrock, J. 2011. Educational Psychology. Jakarta: Salemba Humanika

Swan, et al. 2010. Revisiting Mathematics: Manipulative Materials. APMC, 15 (2): 13-19

Yeni, et al. 2017. Strategi Sekolah Dalam Penguatan Pendidikan Karakter Bagi Siswa dengan Memaksimalkan Peran Orang Tua. Jurnal Manajemen, Kepemimpinan, dan Supervisi Pendidikan, 2 (2): 290-303 
